Rugged Justice 



\section{Rugged Justice}

The Ninth Circuit Court of Appeals and the American West, 1891-1941

\section{David C. Frederick}

With a Foreword by

Justice Sandra Day O'Connor 
University of California Press

Berkeley and Los Angeles, California

University of California Press

London, England

Copyright $\odot 1994$ by The Regents of the University of California

Library of Congress Cataloging-in-Publication Data

Frederick, David C.

Rugged justice : the Ninth Circuit Court of Appeals and the American West, 1891-1941/ David C. Frederick ; foreword by Sandra Day O'Connor.

p. $\mathrm{cm}$.

Includes bibliographical references and index.

ISBN 0-520-08381-4 (alk. paper)

1. United States. Court of Appeals (9th Circuit)-History.

2. Law-West (U.S.)-History. I. Title.

KF8752 9th.F74 1994

$374.78^{\prime} 03-\mathrm{dc} 20$

[347.8073]

93-1309

CIP

Printed in the United States of America

$\begin{array}{lllllllll}9 & 8 & 7 & 6 & 5 & 4 & 3 & 2 & 1\end{array}$

The paper used in this publication meets the minimum requirements of American National Standard for Information Sciences-Permanence of Paper for Printed Library Materials, ANSI Z39.48-1984. $\odot$ 
In large measure the work of a just and able judge is taken for granted. He works in seclusion. His opinions do not attract wide attention, and, if for some unusual circumstance the public notes the decision, the interest is but temporary. He can expect no monuments of stone, no heroic statue in the market place or at the crossroads. These are reserved for the soldier, the sailor, and the executive, the results of whose work is [sic] more obvious. Kingdoms rise and fall, wars are won or lost, and all can see the dramatic result and crown the victor. But the results of judicial work are not spectacular. Their effect is not as a rule obvious, nor can such an effect be readily anticipated or traced. Nevertheless, silently and constantly judges are engaged in building the Temple of Justice in which future generations are to dwell. Justice is essential to happiness. Injustice produces unhappiness and provokes disorder and war. The judge, if he is worthy and successful, wins the battles and the wars that are never fought, that is, his good work prevents wars, and renders unnecessary the struggle of the soldier.

Judge Curtis D. Wilbur, 1931 
